\title{
RETHINKING Eucalyptus globulus Labill. BASED LAND USE SYSTEMS IN SMALLHOLDER FARMERS LIVELIHOODS: A CASE OF KOLOBO WATERSHED, WEST SHEWA, ETHIOPIA
}

\author{
DADI FEYISA ${ }^{1}$, ENDALKACHEW KISSI ${ }^{2}$ ZERIHUN KEBEBEW $^{2 *}$
}

${ }^{1}$ Jimma University College of Agriculture and Veterinary Medicine, Ethiopia

${ }^{2}$ Department of Natural Resources Management, Jimma University College of Agriculture and Veterinary Medicine, P.O. Box 307 Jimma, Ethiopia; e-mail: kebzerh@yahoo.com

* Author for correspondence

\begin{abstract}
Feyisa D., Kissi E., Kebebew Z.: Rethinking Eucalyptus globules Labill. based land use systems in smallholder farmers livelihoods: a case of Kolobo Watershed, West Shewa, Ethiopia. Ekológia (Bratislava), Vol. 37, No. 1, p. 57-68, 2018.

Despite their restriction, smallholder farmers have been continuing growing Eucalyptus globulus in the cultivated land in the central highland of Ethiopia. Literature has shown controversial issues against E. globulus. Therefore, the objective of the study was to investigate the compatibility of $E$. globulus in the smallholder farmers' land use system. Soil samples were collected from five different land uses and analysed for selected physical and chemical properties. The socioeconomic contribution of E. globulus was collected through household surveys from 110 households. Analysis of soil showed that organic carbon (OC), total nitrogen (TN) and cation exchange capacity (CEC) were significantly higher $(\mathrm{P}<0.05)$ under E. globulus compared to the cultivated land. The survey results also showed that the largest proportion (58\%) of households was interested in growing $E$. globulus because of its multiple uses. About $83 \%$ of households responded that E. globulus help them to attain food security through increasing the purchasing power of smallholder farmers to buy agricultural inputs and food. This study has substantiated the role of E. globulus in the land use system of smallholder farmers. Most of the soil fertility indicators were better under E. globulus. The present finding reveals that E. globulus degrade the soil seemingly difficult to generalise. Growing E. globulus must be promoted under appealing land use to enhance smallholder farmers' livelihoods. Removing E. globulus from the land use system may jeopardise the food security situation of many households.
\end{abstract}

Key words: land use systems, farm forestry, soil fertility, rural livelihoods, socioeconomics.

\section{Introduction}

Tree-based land use is mainly the pathway of farming practices change that smallholder farmers undertake to improve their livelihoods (Newby et al., 2014). Many studies indicate 
that tree is a vital component of land use system that sustains rural livelihoods (Pretzsch, 2005). To this effect, smallholder farmers widely plant Eucalyptus globulus in various spatial patterns as component of land use in central highlands of Ethiopia (Mekonnen, 2000). An experience from Arsi Negelle in Ethiopia shows that about 11\% of cropland has been converted to growing Eucalyptus woodlots (Jenbere et al., 2012).

Land is the fundamental component of production in Ethiopia (Teshome et al., 2014) that supports millions of the rural population particularly through agriculture (Mekuria, Aynekulu, 2011). The fear of displacing agricultural crops and the detrimental environmental effect has raised debate over growing E. globulus (Yitaferu et al., 2013). Eucalyptus has been alleged that it affects the physical and chemical properties of soil that leads the Oromia regional state to enact rural land use and administration (proclamation number 56/2002) that discourage growing Eucalyptus on cropland as agriculture is the means of livelihood (Kebebew, Ayele, 2010).

Smallholder farmers' agriculture is believed to tackle food security in the country (Negra et al., 2014). Nevertheless, land degradation coupled with climate change constraints agricultural production at subsistence (Karltun et al., 2013). This bring about millions of the population have failed to attain food security and suffered from severe shortage of food (Karltun et al., 2013). Smallholder farmers undertake farming practices change as an option to keep their livelihood sustenance (Kristjanson et al., 2012; Negra et al., 2014). In Ethiopia, rehabilitation of degraded land has taken attention to increase agricultural production, better off the household well-being. The farmers' experience depicts growing Eucalyptus as an innovative land use approach to normalise the land benefits (Negra et al., 2014).

Despite the controversy over Eucalyptus, there are no concrete empirical evidence that validates the detrimental effect of Eucalyptus on food security and livelihoods (Kidanu et al., 2005; Duguma et al., 2010; Yitaferu et al., 2013; Haile et al., 2014). In Ethiopia, food security is supposed to be addressed through increased agricultural production (Diao, Pratt, 2007; Van der Veen, Tagel, 2011). In contrast, this type of farming requires purchasing power of inputs. However, because of the nature of farming system (Abebaw et al., 2010) smallholder farmers have the limitation of purchasing power. The apparent experience is to undertake land use activities that complement agricultural production (Teshome et al., 2014). Growing Eucalyptus is one form of the land use that helps smallholder to sustain the livelihoods (Jenbere et al.; 2012, Duguma, Hager, 2011). For the rural people, Eucalyptus is a means of safety net (Kebebew, Ayele, 2010). Even if the policy makers discourage growing E. globulus on farm, smallholder farmers in the central highlands of Ethiopia have continued growing E. globulus as one component of land use (Kebebew, Ayele, 2010). The objective of the study was to investigate compatibility of E. globulus under smallholder farmers. This paper tries to answer the following research questions:

- $\quad$ Does the rate of change of soil go beyond the optimum soil fertility?

- How does E. globulus fit into smallholder farmers land use option in context of food security?

\section{Material and methods}

The study was conducted in Kolobo watershed, Adea Berga district of the west Shewa zone, Oromia, Ethiopia. The area where the study is conducted is about $250 \mathrm{ha}$. The district is located at a distance of $74 \mathrm{~km}$ from Addis Ababa 
on the way to Mogor Cement Enterprise. Geographically, it is located between $9^{\circ} 12^{\prime}$ to $9^{\circ} 37^{\prime} \mathrm{N}$ and $38^{\circ} 17^{\prime}$ to $38^{\circ} 36^{\prime} \mathrm{E}$. The altitude of the area ranges from 1,500 to 3,180 $\mathrm{m}$ a.s.l. with an average annual temperature ranges from 15 to $25.5^{\circ} \mathrm{C}$. The annual rainfall of the study area goes up to $1,400 \mathrm{~mm}$. The main rainy season is from June to September and August is the peak rainy month (Kidanu et al., 2005).

Land use complementary effect of E. globulus was investigated through assessing soil properties and socioeconomic benefits. Data was collected from September 2013 to April 2014. A reconnaissance survey was carried out and five land use types were chosen. Under farmers' experience, Eucalyptus is mostly harvested starting from year four (Kidanu et al., 2005). Hence, age of E. globulus was fixed at year four. To minimise soil properties variation because of the slope of the land, first, the area was divided into similar slope category (bottom $2-5 \%$, middle slope 6-9\%, top slope $>9 \%$ ) and five different homogeneous land uses were selected from middle slope category. The elevation is about 2,700 $\mathrm{m}$ a.s.l. Vertisols dominates the area. Land use history shows the land is used for growing barely, wheat, teff, beans and peas at different time. Next plot of size $20 \times 20 \mathrm{~m}$ with three replicates from each land use types was identified. Within a plot, five different points $(2 \times 2 \mathrm{~m})$ were selected, dug to the depth of $30 \mathrm{~cm}$ and finally collected soil sample per plot were composited to get one sample. A total of 15 soil samples were backed in plastic bags and transported to laboratory for analysis. Similar study approach was used by Duguma et al. (2010), Abbasi et al. (2007) and Jenbere et al. (2012).

Collected soil samples were air dried, mixed and passed through a 2-mm sieve for the analysis of selected soil physical and chemical properties at the Jimma University College of Agriculture soil laboratory. Soil texture, bulk density and moisture content were analysed for soil physical properties, whereas soil $\mathrm{pH}$, electrical conductivity (EC), organic carbon (OC), organic matter (OM), total nitrogen (TN), availability of phosphorous (Av.P), cation exchange capacity (CEC) and exchangeable bases were analysed for soil chemical properties. Laboratory analysis was conducted following standard procedures of soil physical and chemical analysis.

Soil texture was analysed following the Boycouos hydrometric method (Abbasi et al., 2007). Hydrogen peroxide $\left(\mathrm{H}_{2} \mathrm{O}_{2}\right)$ was first added to destroy $\mathrm{OM}$ and then sodium hexametaphosphate $\left(\mathrm{NaPO}_{3}\right)_{6}$ was added to disperse the soil. Soil textural classes were determined using the USDA triangular guideline (Brady, Weil, 2002). Soil bulk density was determined by core method after drying the soil samples in an oven at $105^{\circ} \mathrm{C}$ following Abbasi et al. (2007) and Sahlemedhin and Taye (2000). Soil moisture content was measured using gravimeter method as described by Sahlemedhin and Taye (2000).

Soil $\mathrm{pH}-\mathrm{H}_{2} \mathrm{O}$ and EC were estimated from soil-to-water ratio of 1:2.5 and 1:5, respectively (Sahlemedhin, Taye, 2000). The reading of $\mathrm{pH}$ was taken by $\mathrm{pH}$ meter, whereas EC was measured by electrical conductivity meter. The soil OC was measured by the Walkley-Black oxidation method with potassium dichromate $\left(\mathrm{K}_{2} \mathrm{Cr}_{2} \mathrm{O}_{7}\right)$ in a sulphuric acid and converted to soil OM by multiplying it by the factor of 1.724 as described by Nelson and Sommers (1982). TN was determined by the Kjeldahl methods and available phosphorus was determined using the Bray II extraction method (Van Reeuwijk, 1992).

Total exchangeable bases were determined after leaching the soils with ammonium acetate. Amounts of $\mathrm{Ca}^{2+}$ and $\mathrm{Mg}^{2+}$ in the leachate were analysed by atomic absorption spectrophotometer (AAS) and $\mathrm{K}^{+}$and $\mathrm{Na}^{+}$was analysed using flame photo metrically (Chapman, 1965). CEC was determined at soil pH level of 7 after the displacement by using $1 \mathrm{~N}$ ammonium acetate method and then estimated titrimetrically by distillation of ammonium that was displaced by sodium (Chapman, 1965). Percent base saturation (PBS) was calculated by dividing the sum of the base-forming cations ( $\mathrm{Ca}, \mathrm{Mg}, \mathrm{Na}$ and $\mathrm{K}$ ) by the CEC of the soil and multiplying it by 100 (Fageria, 2009).

Structured and semi-structured questionnaires were prepared and pretested to collect the socioeconomic information. The household survey focused on E. globulus and land use under farmers' circumstances. A list of all households living $(\mathrm{N}=561)$ in the watershed was obtained with the help of local administrative bodies (development agents). A sample size was determined using the Cochran (1977) formula. Based on the formula, a total of 110 households were randomly selected for the interview. The information was collected through face-to-face interview with all households $(n=110)$ at their convenient time. Each household was categorised as rich, medium and poor in the kebele. The local administrative body has the record of the wealth status of every household for any development activities. Hence, wealth status of the household was recorded based on the local administrative record. Cost of the fertiliser and income from the Eucalyptus took into account the actual farmer experience. Annual production and productivity of agricultural crops were estimated in quintal \{metric\} (1quintal $\{$ metric $\}=100 \mathrm{~kg}$ ). Farm gate price, cost of fertilisers and income from Eucalyptus were estimated in local currency $(1 \mathrm{ETB}=\$ 0.049 \mathrm{USD})$. It must be known that income from Eucalyptus was collected only on actual income from Eucalyptus sales of farmers' experience. The information obtained through household survey were triangulated through focus group discussion (with development agent and expert from 
district agricultural bureau) and key informant interview (with local elders). Collected information was organised, coded and finally analysed.

Soil physico-chemical properties were analysed using one way analysis of variance (ANOVA). Before the analysis, the data was checked for the assumption of ANOVA. ANOVA was run using SAS software (SAS, 9.2). For variables showing statistically significant difference between treatments $(p<0.05)$, analysis of mean separation was carried out using least significant difference (LSD) at $5 \%$ probability. The socioeconomic data was analysed using descriptive and inferential statistics using SPSS version 20.

\section{Results and discussion}

\section{Soil physical properties}

Soil texture, bulk density and moisture were analysed for soil physical properties. The result showed significant difference $(\mathrm{P}<0.005)$ amongst land use types (Tables 1 and 2$)$. Soil under forest, E. globulus, cultivated and grazing land had clay texture, whereas degraded land had clay loam texture. The proportion of clay was highest (56\%) under forest and lowest (27\%) under degraded land. Soil under E. globulus had significantly higher proportion of clay particles (48\%) than grazing (41\%) and degraded land (27\%). Although the proportion of clay under E. globulus and culti-

T a b l e 1. Mean \pm SEM values for soil textural properties under five land use types.

\begin{tabular}{|l|c|c|c|c|}
\hline Land use & Clay (\%) & Sand (\%) & Silt (\%) & Textural class \\
\hline Forest & $55.67 \pm 1.76^{\mathrm{a}}$ & $21.00 \pm 3.33^{\text {cd }}$ & $21.33 \pm 4.67^{\mathrm{b}}$ & Clay \\
\hline E. globulus & $47.67 \pm 1.76^{\mathrm{b}}$ & $29.00 \pm 3.06^{\mathrm{bc}}$ & $23.33 \pm 4.06^{\mathrm{b}}$ & Clay \\
\hline Cultivated & $41.67 \pm 2.40^{\mathrm{bc}}$ & $35.33 \pm 4.06^{\mathrm{ab}}$ & $24.00 \pm 4.00^{\mathrm{b}}$ & Clay \\
\hline Grazing & $41.00 \pm 1.15^{\mathrm{c}}$ & $15.33 \pm 2.40^{\mathrm{d}}$ & $43.67 \pm 3.53^{\mathrm{a}}$ & Clay \\
\hline Degraded & $27 \pm 2.31^{\mathrm{d}}$ & $42.67 \pm 2.40^{\mathrm{a}}$ & $30.33 \pm 4.67^{\text {ab }}$ & Clay loam \\
\hline PV & 0.0001 & 0.0027 & 0.0417 & - \\
\hline LSD $(0.05)$ & 6.58 & 10.83 & 15.17 & - \\
\hline CV $(\%)$ & 8.20 & 20.15 & 22.18 & - \\
\hline
\end{tabular}

Notes: PV - p value; CV - coefficient of variance; LSD - least significant difference; SEM - standard error mean.

$\mathrm{T}$ a b l e 2. Mean \pm SEM values for SMC and BD under different land use types.

\begin{tabular}{|l|c|c|}
\hline Land use & SMC (\%) & BD $\left(\mathbf{g ~ c m}^{-3}\right)$ \\
\hline Forest & $34.37 \pm 1.78^{\mathrm{a}}$ & $0.97 \pm 0.02^{\mathrm{b}}$ \\
\hline E. globulus & $17.64 \pm 0.55^{\mathrm{c}}$ & $0.87 \pm 0.05^{\mathrm{c}}$ \\
\hline Cultivated & $18.97 \pm 0.87^{\mathrm{c}}$ & $1.14 \pm 0.01^{\mathrm{a}}$ \\
\hline Grazing & $26.67 \pm 0.85^{\mathrm{b}}$ & $1.01 \pm 0.01^{\mathrm{b}}$ \\
\hline Degraded & $12.89 \pm 0.57^{\mathrm{d}}$ & $1.10 \pm 0.02^{\mathrm{a}}$ \\
\hline PV & $<0.0001$ & 0.0002 \\
\hline LSD (0.05) & 3.56 & 0.07 \\
\hline CV $(\%)$ & 8.56 & 3.75 \\
\hline
\end{tabular}

Notes: SMC - soil moistures content; BD - bulk density; PV - p value; CV - coefficient of variance; LSD - least significant difference; SEM - standard error mean. 
vated land was not significantly different, in terms of magnitude, there was a higher proportion of clay under E. globulus (48\%) than cultivated land. The clay fraction under E. globulus was higher when compared to cultivated land. This might be due to high vegetation cover that reduces the clay fractions likely to be lost by selective erosion processes. Clay particles are removed and transported easily than sand particle (Selassie et al., 2015). Those agree with the findings of Lemenih et al. (2005) who had reported high clay content under E. globulus plantation as compared to cultivated and grazing land. This means that soils under E. globulus are more fertile than those of cultivated and degraded land.

Soil under E. globulus had the lowest bulk density $\left(0.87 \mathrm{~g} \mathrm{~cm}^{-3}\right)$ as compared to other land use types. Cultivated land had the highest bulk density $\left(1.14 \mathrm{~g} \mathrm{~cm}^{-3}\right)$. The lower bulk density under E. globulus implies that the soil is less compacted. The optimum range of bulk density of agricultural soil is between 0.9 and $1.2 \mathrm{~g} \mathrm{~cm}^{-3}$ (Frank, 1990). The result shows that soil under $E$. globulus is within the range of the optimum condition for agriculture $\left(0.87--1.14 \mathrm{~g} \mathrm{~cm}^{-3}\right)$ (Table 2). According to Miller and Donahue (1997), bulk densities need to be below $1.4 \mathrm{~g} \mathrm{~cm}^{-3}$ for good plant growth. Yitaferu et al. (2013) had reported lower bulk density $\left(1.07 \mathrm{~g} \mathrm{~cm}^{-3}\right)$ under Eucalyptus compared to cultivated land $\left(1.11 \mathrm{~g} \mathrm{~cm}^{-3}\right)$ in west Gojam Amhara regional state, Ethiopia. Similarly, Selassie and Ayanna (2013), Getachew et al. (2012) and Haile et al. (2014) had reported lower soil bulk density under Eucalyptus compared to cultivated land. The present results agree with the previous findings on the same.

Soil moisture content results showed significant difference under different land use types $(\mathrm{P}$ $<0.05)$. Soil under forest had the highest (34\%) and degraded land had the lowest soil moisture (13\%). Soil moisture under E. globulus (18\%) was lower compared to that under the forest (34\%), under grazing $(27 \%)$, of cultivated land (18\%) but greater than that under degraded land $(12 \%)$. Although the absolute value of soil moisture under E. globulus was lower than the cultivated land, the results were not significantly different at $\mathrm{P}>0.05$ (Table 2). This is probably attributed to short rotation age of E. globulus (4 years). These findings are in agreement with similar study report by Selassie and Ayanna (2013), Getachew et al. (2012) and Haile et al. (2014) who had reported no significant difference on the same between E. globulus and cultivated land.

\section{Soil chemical properties}

Soil under E. globulus had significantly $(\mathrm{P}<0.05)$ lower $\mathrm{pH}$ value $(5.55)$ compared to other land use types. Owing to high cation uptake and low accumulation of exchangeable bases, soil under E. globulus had lower EC $(0.025 \mathrm{ds} / \mathrm{m})$ compared to others (Table 3$)$. Table 4 shows positive and significant correlation between EC and soil $\mathrm{pH}(\mathrm{r}=0.85), \mathrm{Mg}^{2+}(\mathrm{r}=0.63)$ and $\mathrm{Ca}^{2+}(\mathrm{r}=0.63)$. The finding agrees with Haile et al. (2014) who had reported lower $\mathrm{pH}$ value under Eucalyptus woodlots compared to other land use types. However, the $\mathrm{pH}$ value (5.55) of this study is greater than that previous report by Selassie and Ayanna (2013) who reported $\mathrm{pH}$ values of 5.06 and 5.01 under the E. globulus at Abechikeli Mariam and Aferfida Georgis sites, respectively. Duguma et al. (2010) also reported a lower $\mathrm{pH}$ value (5.06) under E. globulus compared to homestead, croplands and grazing lands at central highlands of Ethiopia. The higher $\mathrm{pH}$ (5.55) value of this finding compared to the previous findings is probably attributed to the age of the Eucalyptus as the sample soil was taken under 4 years older Eucalyptus. According to Frank (1990), the pH values of most 
$\mathrm{T} \mathrm{a} \mathrm{b} \mathrm{l} \mathrm{e} \mathrm{3.} \mathrm{Mean} \pm$ SEM values for soil $\mathrm{pH}$ and $\mathrm{EC}$ under different land use systems.

\begin{tabular}{|l|c|c|}
\hline Land use & $\mathbf{p H}$ & EC (ds/m) \\
\hline Forest & $6.52 \pm 0.11^{\mathrm{a}}$ & $0.045 \pm 0.0028^{\mathrm{a}}$ \\
\hline E. globulus & $5.55 \pm 0.14^{\mathrm{b}}$ & $0.025 \pm 0.0028^{\mathrm{c}}$ \\
\hline Cultivated & $6.29 \pm 0.25^{\mathrm{a}}$ & $0.032 \pm 0.004^{\mathrm{bc}}$ \\
\hline Grazing & $6.28 \pm 0.09^{\mathrm{a}}$ & $0.037 \pm 0.0015^{\mathrm{ab}}$ \\
\hline Degraded & $5.60 \pm 0.16^{\mathrm{b}}$ & $0.029 \pm 0.003^{\mathrm{bc}}$ \\
\hline PV & 0.007 & 0.003 \\
\hline LSD $(0.05)$ & 0.52 & 0.01 \\
\hline CV $(\%)$ & 4.58 & 13.16 \\
\hline
\end{tabular}

Notes: $\mathrm{pH}$ - power of hydrogen; EC - electrical conductivity; PV - p value; CV - coefficient of variance; LSD - least significant difference.

T a b le 4. Pearson correlation matrix for the selected soil properties.

\begin{tabular}{|l|l|l|l|l|l|l|l|l|l|l|}
\hline & $\mathbf{p H}$ & EC & OC & TN & AvP & Ca & Mg & Na & K & CEC \\
\hline $\mathbf{p H}$ & 1 & & & & & & & & & \\
\hline $\mathbf{E c}$ & $0.86^{* *}$ & 1 & & & & & & & & \\
\hline $\mathbf{O C}$ & $0.53^{*}$ & $0.54^{*}$ & 1 & & & & & & & \\
\hline $\mathbf{T N}$ & 0.33 & 0.41 & $0.94^{* *}$ & 1 & & & & & & \\
\hline $\mathbf{A v P}$ & $0.74^{* *}$ & $0.66^{* *}$ & $0.66^{* *}$ & $0.63^{*}$ & 1 & & & & & \\
\hline $\mathbf{C a}$ & $0.64^{*}$ & $0.63^{*}$ & $0.84^{* *}$ & $0.75^{* *}$ & $0.75^{* *}$ & 1 & & & & \\
\hline $\mathbf{M g}$ & $0.63^{*}$ & $0.72^{* *}$ & $0.80^{* *}$ & $0.72^{* *}$ & $0.77^{* *}$ & $-0.74^{* *}$ & 1 & & & \\
\hline $\mathbf{N a}$ & 0.36 & 0.49 & $0.60^{*}$ & $0.61^{*}$ & 0.18 & -0.38 & -0.43 & 1 & & \\
\hline $\mathbf{K}$ & $0.75^{* *}$ & $0.67^{* *}$ & $0.66^{* *}$ & $0.62^{*}$ & $0.99^{* *}$ & $-0.75^{* *}$ & $0.77^{* *}$ & 0.19 & 1 & \\
\hline $\mathbf{C E C}$ & 0.46 & 0.47 & $0.93^{* *}$ & $0.94^{* *}$ & $0.72^{* *}$ & $0.91^{* *}$ & $-0.75^{* *}$ & 0.50 & $-0.72^{* *}$ & 1 \\
\hline
\end{tabular}

Notes: $\mathrm{pH}$ - power of hydrogen; EC - electrical conductivity; OC - soil organic carbon; TN - total nitrogen; AvP - available phosphorous; $\mathrm{Ca}$ - calcium; $\mathrm{Mg}$ - magnesium; $\mathrm{Na}$ - sodium; $\mathrm{K}$ - potassium; CEC - cation exchange capacity; ${ }^{* *}$ Correlation is significant at the 0.01 level (two-tailed); ${ }^{\star}$ Correlation is significant at the 0.05 level (twotailed).

T a b l e 5. Mean \pm SEM values for OC, OM, TN and Av.P under different land use systems.

\begin{tabular}{|l|c|c|c|c|}
\hline Land use & OC (\%) & OM (\%) & TN (\%) & Av.P (ppm) \\
\hline Forest & $3.05 \pm 0.22^{\mathrm{a}}$ & $5.27 \pm 0.37^{\mathrm{a}}$ & $0.31 \pm 0.02^{\mathrm{a}}$ & $5.71 \pm 0.48^{\mathrm{a}}$ \\
\hline E. globulus & $2.02 \pm 0.28^{\mathrm{b}}$ & $3.47 \pm 0.49^{\mathrm{b}}$ & $0.25 \pm 0.04^{\mathrm{b}}$ & $2.08 \pm 0.41^{\mathrm{c}}$ \\
\hline Cultivated & $1.24 \pm 0.28^{\mathrm{c}}$ & $2.13 \pm 0.49^{\mathrm{c}}$ & $0.12 \pm 0.02^{\mathrm{c}}$ & $3.99 \pm 0.37^{\mathrm{b}}$ \\
\hline Grazing & $2.24 \pm 0.15^{\mathrm{b}}$ & $3.86 \pm 0.26^{\mathrm{b}}$ & $0.19 \pm 0.01^{\mathrm{b}}$ & $2.93 \pm 0.68^{\mathrm{bc}}$ \\
\hline Degraded & $0.48 \pm 0.11^{\mathrm{d}}$ & $0.82 \pm 0.19^{\mathrm{d}}$ & $0.04 \pm 0.01^{\mathrm{d}}$ & $0.61 \pm 0.37^{\mathrm{d}}$ \\
\hline p-v & 0.0001 & 0.0001 & 0.0001 & 0.003 \\
\hline LSD (0.05) & 0.62 & 1.07 & 0.06 & 1.39 \\
\hline CV (\%) & 18.26 & 18.20 & 15.77 & 24.22 \\
\hline
\end{tabular}

Notes: OC - soil organic carbon; OM - organic matter; TN - total nitrogen; Av.P - available phosphorous; PV - p value; $\mathrm{CV}$ - coefficient of variance; LSD - least significant difference. 
agricultural soils are in the range of 5.5-7. The $\mathrm{pH}$ value (5.5) under E. globulus is under medium rating categories implying that the land is suitable for growing crops from soil $\mathrm{pH}$ point of views. The experiences of cropping on the land that has been under Eucalyptus plantation in west Gojam Amhara regional state, Ethiopia, verify the same (Yitaferu et al., 2013). This result argues against the detrimental effect of Eucalyptus on soil pH, rather soil under Eucalyptus plantation has a good potential for cropping.

Soil OC, OM, TN and available phosphorous are presented in Table 5. Significant difference $(\mathrm{P}<0.05)$ was observed amongst the land use types. Soil under forest had the highest soil OC, OM, TN and available phosphorous, whereas soil under degraded land had the lowest soil OC, OM, TN and available phosphorous. Soil under E. globulus had significantly higher soil OC (2.02\%), OM (3.47\%) and TN (0.25\%) compared to cultivated land. The soil OC and OM under forest and E. globulus were rated as medium categories; whereas low under cultivated land. The findings agree with similar studies (Abbasi et al., 2007; Duguma et al., 2010; Getachew et al., 2012; Haile et al., 2014). Abbasi et al. (2007) had reported differences in OM amongst land use types. Getachew et al. (2012) had reported more OC than farmland. Haile et al. (2014) had reported more OM under grassland and woodlot compared to cereal farms. Duguma et al. (2010) had more soil OC and TN under small-scale woodlot than pasturelands and cereal farms. Soil under E. globulus had significantly $(\mathrm{P}<0.05)$ lower available phosphorous than cultivated land (Table 5). There is positive and significant $(r=0.74)$ relationship between available phosphorous and $\mathrm{pH}$ (Table 4). Soil pH influences the availability of phosphorus. Phosphorus fixation takes place at lower $\mathrm{pH}$ (Kebede, Raju, 2011). Tisdale et al. (2002) also noted that maximum availability of phosphorus generally occurs in a $\mathrm{pH}$ range of 6.0-7. This finding agrees with Getachew et al. (2012), Haile et al. (2014) and Yitaferu et al. (2013) findings on the available phosphorous under Eucalyptus. The TN is directly and significantly associated with OC $(\mathrm{r}=0.94)$ and CEC $(\mathrm{r}=0.94)$ (Table 4). The result is similar to Mengist (2011) who had reported higher soil nitrogen under $E$. globulus compared to cultivated land.

$\mathrm{CEC}$, percentage of base saturation (PBS) and exchangeable $\mathrm{Ca}, \mathrm{Mg}$ and $\mathrm{K}$ were significantly $(\mathrm{P}<0.05)$ affected by the land use systems, whereas exchangeable $\mathrm{Na}$ was not statistically affected by the land use systems (Table 6). Soil under E. globulus had higher CEC value (30.78 $\mathrm{Cmol}(+) /$

T a b l e 6. Mean \pm SEM values for CEC, exchangeable bases and PBS under different land use types.

\begin{tabular}{|l|c|c|c|c|c|c|c|}
\hline \multirow{2}{*}{ LU } & CEC & Ca & Mg & Na & K & \multirow{2}{*}{$\begin{array}{c}\text { Total } \\
\text { cation }\end{array}$} & \multirow{2}{*}{ PBS (\%) } \\
\cline { 2 - 9 } & \multicolumn{7}{|c|}{ Cmol(+)/kg } \\
\hline F & $37.40 \pm 1.65^{\mathrm{a}}$ & $18.50 \pm 1.21^{\mathrm{a}}$ & $8.00 \pm 0.58^{\mathrm{a}}$ & $0.33 \pm 0.01$ & $1.14 \pm 0.1^{\mathrm{a}}$ & 27.97 & $74.7 \pm 0.79^{\mathrm{a}}$ \\
\hline E & $30.78 \pm 0.87^{\mathrm{b}}$ & $11.86 \pm 1.95^{\mathrm{b}}$ & $2.30 \pm 1.01^{\mathrm{c}}$ & $0.31 \pm 0.02$ & $0.42 \pm 0.08^{\mathrm{cd}}$ & 14.89 & $48.4 \pm 3.21^{\mathrm{c}}$ \\
\hline C & $25.09 \pm 0.70^{\mathrm{c}}$ & $11.21 \pm 0.41^{\mathrm{b}}$ & $2.97 \pm 0.25^{\mathrm{c}}$ & $0.29 \pm 0.00$ & $0.80 \pm 0.08^{\mathrm{b}}$ & 15.27 & $61 \pm 2.74^{\mathrm{b}}$ \\
\hline G & $28.21 \pm 1.09^{\mathrm{b}}$ & $13.50 \pm 0.85^{\mathrm{b}}$ & $5.83 \pm 0.44^{\mathrm{b}}$ & $0.31 \pm 0.00$ & $0.60 \pm 0.14^{\mathrm{bc}}$ & 20.24 & $71.5 \pm 2.00^{\mathrm{a}}$ \\
\hline D & $16.96 \pm 1.46^{\mathrm{d}}$ & $6.17 \pm 0.60^{\mathrm{c}}$ & $1.30 \pm 0.21^{\mathrm{c}}$ & $0.29 \pm 0.02$ & $0.14 \pm 0.05^{\mathrm{d}}$ & 7.90 & $46.4 \pm 2.32^{\mathrm{c}}$ \\
\hline PV & $<0.0001$ & 0.0012 & 0.0003 & 0.3512 & 0.0003 & & $<0.0001$ \\
\hline LSD & 3.05 & 3.92 & 2.04 & & 0.28 & & 7.62 \\
\hline CV $(\%)$ & 5.84 & 16.99 & 20.52 & 8.94 & 23.80 & & 6.70 \\
\hline
\end{tabular}

Notes: LU - land use; F - forest; E - E. globulus; C - cultivated; G - grazing; CEC - cation exchange capacity; BPS - percentage base saturation; $\mathrm{PV}-\mathrm{p}$ value; $\mathrm{CV}$ - coefficient of variance. 
$\mathrm{kg})$ compared to grazing $(28.21 \mathrm{Cmol}(+) / \mathrm{kg})$, cultivated land $(25.09 \mathrm{Cmol}(+) / \mathrm{kg})$ and degraded land $(16.96 \mathrm{Cmol}(+) / \mathrm{kg})$. The CEC ratings under forest and E. globulus were high. This variation might be attributed to the high accumulation of $\mathrm{OM}$ and high clay percentage under E. globules and forest land use types. There is positive and strong significant association between CEC and Clay $(r=0.97)$ and CEC and OM $(r=0.93)$ (Table 4). The lowest values of exchangeable Mg and $\mathrm{K}$ were also observed under E. globulus compared to cultivated land. This study disagrees with Duguma et al. (2010) who had reported higher CEC under cereal farms compared to Eucalyptus.

\section{Eucalyptus globulus in land use system of smallholder farmers}

E. globulus is an integral element of smallholder farmers' land use system in the study area. Table 7 shows the summary of the household characteristics. The response rate to the questionnaires was $100 \%$. The family size of the household ranges between 2 and 15 with an average of 7 persons, which is higher than of the west Shewa zone, 5.3 persons per household. About $45 \%$ of the households belong to medium wealth category. The landholding size per household ranges between 0.25 and 14 ha with an average of 3.4 ha. The average landholding size of the households is more than the west Shewa zone of average landholding size who posses on 1.93 ha. About $55 \%$ of the households had the landholding size of less than the average landholding size, whilst only about $22 \%$ of the households had the landholding size of more than 5 ha.

Assessment of household land allocation showed that about $46 \%$ of land was put under cultivation. Only $16 \%$ of the land was put under E. globulus showing less displacement of cultivated land for growing E. globulus. The rich households planted (1.1 ha) more E. globulus as compared to poor $(0.66 \mathrm{ha})$ and medium $(0.73 \mathrm{ha})$ households. The difference was statistically significant as determined by one way ANOVA $(\mathrm{F}(2,107)=5.724, \mathrm{P}=0.04)$. The largest proportion of households (58\%) preferred E. globulus because of its multiple uses. Only $22 \%$ and $20 \%$ of the households prefer E. globulus because of its fast growth and easy management, respectively. The need for E. globulus showed that households prefer to plant Eucalyptus on cultivated land (40\%), grazing land (34\%) and degraded land (26\%). The finding agrees with Jenbere et al. (2012) who had reported the rich households plant Eucalyptus more than the poor and medium households.

Analysis of Eucalyptus in household food security endeavour shows smallholder farmers' strive to produce more food from what they produce. Table 8 shows crop production and pro-

T a b l e 7. Summary of household characteristics.

\begin{tabular}{|l|c|c|c|c|c|}
\hline HH characteristics & N & Min & Max & Mean & Valid Percent \\
\hline Age classes(no) & 110 & 27 & 71 & 45 & 100 \\
\hline Family size (no) & 110 & 2 & 15 & 7 & 100 \\
\hline Landholding size(ha) & 110 & 0.25 & 14 & 3.4 & 100 \\
\hline Land under E. globulus (ha) & 110 & 0.13 & 3 & 0.80 & 100.0 \\
\hline Wealth status(no) & 110 & & & & 44.5 \\
\hline Medium & 49 & & & & 29.1 \\
\hline Poor & 32 & & & & 26.4 \\
\hline Rich & 29 & & & & \\
\hline
\end{tabular}


ductivity of major crops at household level. The rich households produce, on an average, 18.48 quintal per year. The medium and poor households produce 18.35 and 15.16 quintal per year, respectively. The poor, medium and rich households need 15.22, 16.27 and 16.17 quintal per year, respectively, to support their families. Currently, most households support their families between 9 and 11 months from what they produce implying to buy food crops for the remaining months. Without using the inputs, the annual production was below the bottom line of what is required to support their families. To increase agricultural production, smallholder farmers' use input such as commercial fertilisers. An average poor, medium and rich households need 3247.92, 3545.19 and 3380.20 ETB, respectively, to buy fertilisers (Table 9). This is equivalent to selling, for instances, $4.39,4.86$ and 4.61 quintal of barley, respectively. Smallholder farmers need cash to buy inputs to increase productivity. E. globulus is assists to obtain cash for buying inputs and food. A land user can increase agricultural production when E. globulus became a component of the land use. Land under E. globulus reduced the quantity of fertilisers to be purchased as E. globulus does not need fertiliser application. Therefore, smallholder farmers saved some cash which could have been used to purchase commercial fertilisers. Growing E. globulus need less labour implying the labour can shift to agricultural production. The absence of E. globulus from the land use systems has shifted all food secure households to food insecure because of the fact that 4 quintal is deducted from average production (17.33 quintal) to purchase fertiliser and then 13.33 quintal is less than the average production needed to support family (15.89 quintal). Therefore, restricting smallholder farmers from planting E. globulus may negatively affect their livelihoods. E. globulus

T a b le 8 . Crops productivity per hectare with and without inputs at household level.

\begin{tabular}{|c|c|c|c|c|}
\hline & \multicolumn{4}{|c|}{ Wealth categories } \\
\hline & Poor & Medium & Rich & Average \\
\hline $\begin{array}{l}\text { Average annual production [quintal (metric)] } \\
\text { Total production }\end{array}$ & 15.16 & 18.35 & 18.48 & 17.33 \\
\hline Production needed to support family & 15.22 & 16.27 & 16.17 & 15.89 \\
\hline Food self sufficiency (months) & 9.88 & 10.65 & 10.8 & \\
\hline \multicolumn{5}{|l|}{$\begin{array}{l}\text { Average productivity per ha [quintal (metric)] } \\
\text { Without inputs }\end{array}$} \\
\hline Barley & 3.16 & 4.33 & 3.59 & 3.69 \\
\hline Wheat & 4.44 & 4.82 & 4.5 & 4.59 \\
\hline Peas & 1.19 & 2.04 & 2.43 & 1.89 \\
\hline Beans & 2.17 & 3 & 3.43 & 2.87 \\
\hline Teff & 3.52 & 3.47 & 3.26 & 3.42 \\
\hline Average & 2.89 & 3.53 & 3.44 & 3.29 \\
\hline \multicolumn{5}{|l|}{ With inputs } \\
\hline Barley & 15.3 & 16.3 & 16.9 & 16.17 \\
\hline Wheat & 19.9 & 20.2 & 21 & 20.37 \\
\hline Peas & 3.7 & 6 & 6.8 & 5.5 \\
\hline Beans & 6.5 & 8.9 & 9.2 & 8.2 \\
\hline Teff & 13.5 & 14.6 & 14.2 & 14.1 \\
\hline Average & 11.8 & 13.2 & 13.6 & 12.87 \\
\hline
\end{tabular}


made a substantial contribution to the income of the households, even more than agricultural crops (Selassie, Ayanna, 2013, Kebebew, Ayele, 2010).

Table 10 showed that $83 \%$ of households were food secure because of E. globulus contribution to their income. Of the total households, $45.5 \%$ preferred to sale E. globulus in the case of emergency as compared to crops and livestock. The cash obtained from selling the Eucalyptus has filled the food shortage gaps of the families. Eucalyptus trees are regarded as insurance resource or life saviour, because they are cut and readily converted to cash during critical needs. The average annual income from E. globulus under poor, medium and rich households are 11219.27, 12207.48 and $15024.14 \mathrm{ETB} / \mathrm{ha}$, respectively. In the study area,

T a b l e 9. Farm gate price of different crops at household level.

\begin{tabular}{|c|c|c|c|c|}
\hline & \multicolumn{4}{|c|}{ Wealth categories } \\
\hline & Poor & Medium & Rich & Average \\
\hline \multicolumn{5}{|c|}{$\begin{array}{l}\text { Price of crops and inputs (ETB) } \\
\text { Crops price }\end{array}$} \\
\hline Barley & 739.84 & 729.08 & 732.76 & 733.89 \\
\hline Wheat & $1,043.75$ & $1,030.61$ & $1,048.28$ & $1,040.88$ \\
\hline Peas & 800 & 823.98 & 812.07 & 812.02 \\
\hline Beans & 695.31 & 687.76 & 689.66 & 690.91 \\
\hline Teff & $1,515.63$ & $1,569.39$ & $1,593.1$ & $1,559.37$ \\
\hline Cost of inputs per year & $3,247.92$ & $3,545.19$ & $3,380.2$ & 3391.1 \\
\hline \multicolumn{5}{|c|}{ Amount of crops sold to buy inputs [quintal(metric)] } \\
\hline Barley & 4.39 & 4.86 & 4.61 & 4.62 \\
\hline Wheat & 3.11 & 3.44 & 3.22 & 3.26 \\
\hline Peas & 4.06 & 4.3 & 4.16 & 4.17 \\
\hline Beans & 4.67 & 5.15 & 4.9 & 4.91 \\
\hline Teff & 2.14 & 2.26 & 2.12 & 2.17 \\
\hline Average & 3.68 & 4 & 3.8 & 3.83 \\
\hline
\end{tabular}

T a b l e 10. Household income contribution of E. globulus.

\begin{tabular}{|c|c|c|c|c|c|c|}
\hline & \multicolumn{6}{|c|}{ Wealth categories } \\
\hline & Poor & Medium & Rich & Average & Total & $\%$ \\
\hline \multicolumn{7}{|l|}{ Rotation age (years) } \\
\hline 4 years & 16 & 22 & 13 & & 51 & 46.36 \\
\hline 5 years & 16 & 27 & 16 & & 59 & 53.64 \\
\hline \multicolumn{7}{|l|}{ Rotation age (years) coppicing } \\
\hline 3 years & 16 & 30 & 18 & & 64 & 58.18 \\
\hline 4 years & 16 & 19 & 11 & & 46 & 41.82 \\
\hline $\begin{array}{l}\text { Average annual income from } E \text {. } \\
\text { globulus (ETB) }\end{array}$ & $11,219.2$ & $12,207.48$ & $15,024.14$ & $12,816.96$ & & \\
\hline \multicolumn{7}{|c|}{ Income from E. globulus satisfy household food security } \\
\hline Yes & 20 & 43 & 28 & & 91 & 82.7 \\
\hline No & 12 & 6 & 1 & & 19 & 17.3 \\
\hline
\end{tabular}


E. globulus can start to provide income from the first and second rotation of 4 or 5 and 3 or 4 years, respectively, excluding in-between benefits. Kebebew and Ayele (2010) reported that E. globulus serves as a cash crop to smallholder farmers and contributed significantly to farmers livelihoods. Smallholder farmers harvest E. globulus starting from year 3 to 4 depending on the perceived products.

\section{Conclusion}

The results of the study showed higher soil bulk density, soil OC content and TN under Eucalyptus as compared to cultivated and degraded land, which implies less detrimental effect of Eucalyptus on soil fertility. The clay particles and CEC were significantly higher under the E. globulus compared with all land uses except forest. From livelihoods perspective, E. globulus plays an important role in addressing food security. The results also showed that $82.7 \%$ households were food secure from the income obtained from E. globulus. The average annual income from E. globulus under poor, medium and rich households are 11 219.27, 12 207.48 and $15024.14 \mathrm{ETB} / \mathrm{ha}$, respectively. If E. globulus can be restricted from the land use systems, the livelihoods of all households depending on the activity will be negatively affected. Therefore, the issue of discouraging E. globulus must take into account the current contribution of E. globulus to agricultural production.

\section{Acknowledgements}

The authors would like to thank Oromia Bureau of Agriculture for financing the study. The gratitude goes to Holleta Agricultural Research Centers and JUCAVM for their collaboration during soil laboratory analysis. The author would like to thank all individuals and organisations who have contributed to the success of the study. Special thanks go to households of Kolobo watershed for their willingness for the interview and providing genuine information.

\section{References}

Abbasi, M.K., Zafar, M. \& Khan S.R. (2007). Influence of different land-cover types on the changes of selected soil properties in the mountain region of Rawalakot Azad Jammu and Kashmir nutrient cycling. Agroecosystem, 78, 97-110. DOI: $10.1007 /$ s10705-006-9077-z.

Abebaw, D., Fentie, Y. \& Kassa B. (2010). The impact of a food security program on household food consumption in Northwestern Ethiopia: A matching estimator approach. Food Policy, 35, 286-293. DOI: 10.1016/j.foodpol.2010.01.002.

Brady, N.C. \& Weil R.R. (2002). The nature and properties of soils. New Jersey: Prentice-Hall.

Chapman, H.D. (1965). Cation exchange capacity. In C.A. Black, L.E. Ensminger \& F.E. Clark (Eds.), Methods of soil analysis. Agronomy, 9, 891-901.

Cochran, W.G. (1977). Sampling techniques. New York: John Wiley and Sons.

Diao, X. \& Pratt A.N. (2007). Growth options and poverty reduction in Ethiopia - An economy-wide model analysis. Food Policy, 32, 205-228. DOI: 10.1016/j.foodpol.2006.05.005.

Duguma, L.A., Hager, H. \& Sieghardt M. (2010). Effects of land use types on soil chemical properties in smallholder farmers of central highland Ethiopia. Ekológia (Bratislava), 29, 1-14. DOI: 10.4149/ekol_2010_01_1.

Duguma, L.A. \& Hager H. (2011). Farmers' assessment of the social and ecological values of land uses in central highland Ethiopia. Environ. Manag., 47, 969-982. DOI: 10.1007/s00267-011-9657-9.

Fageria, N.K. (2009). The use of nutrients in crop plants. New York: CRC Press.

Frank, B. (1990). Interpreting soil test results: What do all the numbers mean? Collingwood: CSIRO Publishing.

Getachew, F., Abdulkadir, A., Lemenih, M. \& Fetene A. (2012). Effects of different land uses on soil physical and chemical properties in Wondo Genet Area, Ethiopia. New York Science Journal, 5(11), 110-118. DOI: 10.7537/ marsnys051112.16. 
Haile, G., Lemenih, M., Itanna, F. \& Senbeta F. (2014). Impacts of land uses changes on soil fertility, carbon and nitrogen stock under smallholder farmers in central highlands of Ethiopia: Implication for sustainable agricultural landscape management around Butajira area. New York Science Journal, 7(2), 27-44. DOI: 10.7537/marsnys070214.04.

Jenbere, D., Lemenih, M. \& Kassa H. (2012). Expansion of eucalypt farm forestry and its determinants in Arsi Negelle district, South central Ethiopia. Small-Scale Forestry, 11, 389-405. DOI: 10.1007/s11842-011-9191-x.

Karltun, E., Lemenih, M. \& Tolera M. (2013). Comparing farmers' perception of soil fertility change with soil properties and crop performance in Beseku, Ethiopia. Land Degrad. Dev., 24, 228-235. DOI: 10.1002/ldr.1118.

Kebebew, Z. \& Ayale G. (2010). Profitability and household income contribution of growing Eucalyptus globulus Labill. to smallholder farmers: the case of central Highland of Oromia, Ethiopia. European Journal of Applied Sciences, 2, 25-29.

Kebede, Y. \& Raju S.A.J. (2011). Effect of land use/land cover change on soil properties in the Hare River Watershed, Ethiopia. The Ecoscan, An International Quarterly Journal of Environmental Sciences, 5, 69-74.

Kidanu, S., Mamo, T. \& Stroosnijder L. (2005). Biomass production of Eucalyptus boundary plantations and their effect on crop productivity on Ethiopian highland Vertisols. Agrofor. Syst., 63, 281-290. DOI: 10.1007/s10457-005-5169-z.

Kristjanson, P., Neufeldt, H., Gassner, A., Mango, J., Kyazze, F.B., Desta, S., Sayula, G., Thiede, B., Förch, W., Thornton, P.K. \& Coe R. (2012). Are food insecure smallholder households making changes in their farming practices? Evidence from East Africa. Food Security, 4, 381-397. DOI: 10.1007/s12571-012-0194-z.

Lemenih, M., Karltun, E. \& Olsson M. (2005). Assessing soil chemical and physical property responses to deforestation and subsequent cultivation in smallholders farming system in Ethiopia. Agric. Ecosyst. Environ., 105, 373-386. DOI: 10.1016/j.agee.2004.01.046.

Mekonnen, A. (2000). Valuation of community forestry in Ethiopia: A contingent valuation study of rural households. Environmental \& Developmental Economics, 5, 289-308.

Mekuria, W. \& Aynekulu E. (2011). Exclosure land management for restoration of the soils in degraded communal grazing lands in northern Ethiopia. Land Degrad. Dev., 24(6), 528-538. DOI: 10.1002/ldr.1146.

Mengist, M. (2011). Eucalypts plantations in the highlands of Ethiopia revisited: A comparison of soil nutrient status after the first coppicing. Master Thesis - Mountain Forestry Program.

Miller, R.W. \& Donhue R.L. (1997). Soil in our environment. Prentice-Hall.

Negra, C., Vermeulen, S., Barioni, L.G., Mamo, T., Melville, P. \& Tadesse M. (2014). Brazil, Ethiopia, and New Zealand lead the way on climate-smart agriculture. Agriculture \& Food Security, 3, 19. DOI: 10.1186/s40066-014-0019-8.

Nelson, D.W. \& Sommers I.E. (1982). Total carbon, organic carbon and organic matter. Chemical and microbiological properties. American Society of Agronomy, 9, 639-679.

Newby, J., Cramb, R. \& Sakanphet S. (2014). Forest transitions and rural livelihoods: Multiple pathways of smallholder Teak expansion in Northern Laos. Land, 3, 482-503. DOI: 10.3390/land3020482.

Pretzsch, J. (2005). Forest related rural livelihood strategies in national and global development. Forests, Trees \& Livelihoods, 15, 115-127. DOI: 10.1080/14728028.2005.9752515.

Sahlemedhin, S. \& Taye B. (2000). Procedure for soil and plant analysis. Technical Paper No. 74. National Soil Research Center: Ethiopian Agricultural Research Organization.

Selassie, Y.G. \& Ayanna G. (2013). Effects of different land use systems on selected physic-chemical properties of soils in northwestern Ethiopia. J. Agric. Sci., 5, 112-120. DOI: 10.5539/jas.v5n4p112

Selassie, Y.G., Anemut, F. \& Addisu S. (2015). The effects of land use types, management practices and slope classes on selected soil physico-chemical properties in Zikre watershed, North-Western Ethiopia. Environmental Systems Research, 4, 3. DOI: 10.1186/s40068-015-0027-0.

Teshome, A., Graaff, J., Ritsema, C. \& Kassie M. (2014). Farmers' perceptions about the influence of land quality, land fragmentation and tenure systems on sustainable land management in the north western Ethiopian highlands. Land Degrad. Dev., 27(4), 884-898. DOI: 10.1002/ldr.2298.

Tisdale, S., Nelson, W., Beaton, J. \& Havlin J. (2002). Soil fertility and fertilizers. New Jersey: Prentice-Hall.

Van der Veen, A. \& Tagel G. (2011). Effect of policy interventions on food security in Tigray, Northern Ethiopia. Ecology \& Society, 16, 18. http://www.ecologyandsociety.org/vol16/iss1/art18/.

Van Reeuwijk, L.P. (1992). Procedures for soil analysis. Wageningen: International Soil Reference and Information Center (ISRIC).

Yitaferu, B., Abewa, A. \& Amare T. (2013). Expansion of eucalypts woodlots in the fertile soils of the highlands of Ethiopia: Could it be a treat on future cropland use? J. Agric. Sci., 58, 97-107. DOI: 10.5539/jas.v5n8p97. 